\section{Challenges of Online Teaching during the pandemic COVID-19: Reports from Moldovan Vocational Education and Training Teachers}

\section{Oleg Stiopca}

State Agrarian University of Moldova, Republic of Moldova

\section{Robert Cobb Jr.}

North Carolina Agricultural and Technical State University, USA

\section{Paula E. Faulkner}

North Carolina Agricultural and Technical State University, USA

Submitted: 24 August 2020

Accepted: 02 December 2020

Published: 31 December 2020

Corresponding author:

Paula E. Faulkner

DOI: 10.19044/esj.2020.v16n34p195

(c) Copyright 2020 Faulkner E.P. et.al Distributed under Creative Commons BY-NC-ND 4.0 OPEN ACCESS

\begin{abstract}
Teachers worldwide are experiencing challenges with transitioning from

face-to-face to online teaching during the pandemic COVID-19. Policymakers, school administrators, students, parents, and teachers have all been impacted. Moldovan educational policies and infrastructures are being re-visited to identify the best strategies for supporting its teachers during this time. The purpose of this case study was to assess Moldovan Vocational Education and Training (VET) teachers' challenges faced teaching online. Data were analyzed by researchers reviewing interview notes to ascertain the main points gathered from teachers occurred during the focus group interview. The focus group with mostly female teachers revealed their desire to gain online teaching training and frustration over a lack of stable Internet connection during lessons. It was concluded that teachers' needs should be shared with policymakers and school administrators to ensure technology training and reliable technology devices for at home use be provided while schools are closed. Based on conclusions, the following recommendations would be to assess student's needs to ensure their needs are aligned with teachers' needs so the best teaching and learning can occur.
\end{abstract}

Keywords: Pandemic COVID-19, Moldova, online teaching, training, vocational education teachers 


\section{Introduction}

Twenty-first-century teachers need skills to develop lessons for traditional classroom instruction while also applying them to digital teaching environments (The Resilient Educator, 2020). While it can be challenging to support the quality of traditional, face-to-face teaching, it may be even more challenging to support quality in online teaching (Horvitz \& Beach, 2011). While a considerable amount of research has investigated student engagement in online courses (Angelino, Williams, \& Natvig, 2007; Oliver, 1999), the question of teacher engagement in online environments has not received significant attention. The recent COVID-19 pandemic has exposed tremendous lapses in Internet infrastructure, a digital divide, and challenges related to decisions to quickly move education to an online environment without providing educators the necessary training to teach online. It is important to understand teachers as they are the group of people charged with teaching, training, encouraging, and inspiring pupils to learn (Okeke-James, Igbokwe, Anyanwu \& Obineme, 2020). This is especially the case for teachers worldwide who are being impacted by the pandemic COVID-19 (Ozur, 2020) on secondary and postsecondary levels. This is the case for teachers in various fields of study and academic disciplines (Flaherty, 2020), ranging from science, technology, English, business, history, and vocational education. This study's focus is on Vocational Education and Training (VET), which is an educational system that prepares individuals for work (Ganefri \& Hyadat, 2014).

Vocational Education is a practice-oriented approach to education, emphasizing what to do in the workplace due to either learning to meet the career requirements or improving student performance on the skill level to be possessed (Mustapa, Ibrahim, \& Yusoff, 2014). Technical and Vocational Education should be considered a medium that can be combined with elements of e-learning in educational technology (Mustapa, et al. 2014). During vocational education and training, teachers are encouraged to demonstrate competencies for digital tools (Cedefop, 2020). VET Teachers are essential for preparing their students for the workplace. Policymakers and school administrators must be aware of teachers' needs for teaching and learning online, especially during this time of COVID-19. For instance, teachers often ask, "How can I effectively teach online?" The need to support teachers with being effective is crucial, as Save the Children (2020) warned, "The Covid-19 pandemic has caused an "unprecedented education emergency" with up to 9.7 million children affected by school closures" (p. 1). Alarmingly, the new norm for online teaching and learning will be here for a while, as supported by $\mathrm{Li}$ and Lalani (2020), who said, "The changes Coronavirus has caused might be here to stay" (p.1). 


\section{Problem Statement}

In April 2020, The Institute for European Policies and Reforms (IPRE), Privesc.eu, and the Hanns Seidel Foundation held videoconferences to decide how best to transition educational programs from traditional face-toface to online teaching due to the pandemic COVID-19 (Institute for European Policies and Reforms, 2020). More discussions were held to differentiate between online delivery tools and distance learning since they are slightly different teaching and learning processes. Additionally, the main problem was challenges faced by Vocational Education and Training Teachers. For instance, in 2019, before the pandemic, a Moldovan program was established to empower vocational education teachers with digital teaching skills. Teachers received modules for how to use digital tools. The goal was also to learn how teachers assimilated to using new informational technology and understanding digital content. Additionally, The Chisinau City Hall offered an estimated 2,000 online lessons for teachers, students, and parents to educate them on how to access video lessons without an Internet connection (OECD, n.d.). Regardless of these support efforts, teachers still reported being illprepared to teach online.

The Moldovan Ministry of Education, Culture, and Research of Moldova (2020) reported:

We know that in the first week of the pandemic, more than 18,000

children did not participate in the educational process, and 3000 teachers did not have a device on which to work. In this respect, 20 million lei were identified to purchase laptops for disadvantaged teachers and students. We do not know how long this pandemic will last and how it will evolve, which is why we all understand that the health of children and teachers is now a priority. (p. 1)

\section{Vocational Education and Training High Schools and Teachers}

The partnership between the researchers and the Vocational Education and Training Schools was established based on support by The United States Agency for International Development for High-Value Agriculture Activity (USAID/HVAA). The Vocational Education and Training Schools are also significant for this study due to teachers' varied backgrounds and the specific occupations they deliver. The goal of USAID/HVAA is to cultivate a modern agriculture sector in Moldova. It also seeks to increase rural prosperity by improving Moldova's economic well-being by increasing the workforce's quality in high-value agriculture (USAID, 2020). The VET Teachers are invaluable as they prepare students for the Republic of Moldova workforce and beyond.

The Nisporeni School is located 40 miles from Chisinau, the capital city, with a student enrollment of 280 (150 females; 130 males). Students can 
select from six occupations related to the agriculture sector, such as pomiculture, viticulturist and winemaking, and berry-producing and processing.

The Bubuieci School is located 10 miles from Chisinau, with a student enrollment of 267 (165 females; 102 males). Students can select from six occupations ranging from floristry to beekeeping. Table 1 provides the VET Schools' demographic profile, and Table 2 provides the demographic profile of the VET Teachers. Study participants included eight teachers ( 5 females; 3 males) at The Nisporeni School and ten teachers ( 8 females; 2 males) at The Bubuieci School.

\section{Purpose of the Study and Objectives}

The purpose of this exploratory case study was to assess challenges Moldovan Vocational Education and Training (VET) teachers faced for teaching online during the pandemic COVID-19. The following objectives were developed to guide the study. Objective 1: "What is the demographic profile of Moldovan VET Schools and Teachers" and Objective 2: "What do participants require for teaching online?"

\section{Methodology}

A two-hour focus group was held on July 31, 2020, via Zoom.com. Merriam and Tisdell (2016) support using a basic qualitative approach when the study's purpose involves gaining a better understanding of individuals' interpretation and the meaning of their experiences. Purposive sampling was used to select teachers of the two Moldovan VET Schools. Researchers can select participants and research sites associated with the phenomenon and research problem being studied (Creswell, 2007). Invitations to participate in the study were sent to all teachers at the two VET Schools. As a result, eighteen teachers accepted the invite and were then provided informed consent forms and the interview questions.

\section{Data Collection}

A focus group was conducted because it offered "a way to collect qualitative data, which involved engaging a small number of people in an informal group discussion, 'focused' around a particular topic (Wilkinson, 2004). Focus groups allow for less threatening settings, where participants discuss opinions and thoughts (Krueger \& Casey, 2000). They usually last between 1-2 hours (Morgan, 1997; Vaughn, Schumm, \& Sinagub, 1996) and consist of between 6 and 12 participants (Baumgartner, Strong, \& Hensley, 2002; Bernard, 1995; Johnson \& Christensen, 2004; Krueger, 1988, 1994, 2000; Langford, Schoenfeld, \& Izzo, 2002; Morgan, 1997; Onwuegbuzie, Jiao, \& Bostick, 2004). 
The following open-ended questions were asked during the focus group:

- What existing infrastructures for conducting online learning are currently in place?

- What access to technology devices and Internet connection is available?

- Is there a need for you to know how to use online teaching platforms?

- What other challenges have you experienced during the transition from face-to-face to teaching online during the COVID-19 pandemic?

\section{Data Analysis}

Despite the abundance of research studies related to the benefit of conducting focus groups, there are limited research studies on how to analyze data in the social sciences (Onwuegbuzie, Dickinson, Leech, \& Zoran, 2009). However, there are several data analysis techniques best suited for studies such as the current study. The researchers followed data analysis strategies recommended by Creswell (2013), which supports researchers reviewing interview notes and reading transcriptions multiple times to ascertain the main points gathered during the focus group interview.

Conversation analysis also allows participants to interact during conversational interactions (Myers, 1998). Then, summative content analysis was employed (Hsieh \& Shannon, 2005; Neuendorf, 2017), supporting researchers interacting with the transcribed interviews through notetaking and identifying key concepts. To describe the insights (i.e., perspectives, beliefs, and practices) of teachers, the researchers also used Saldana's (2013) inductive, emergent coding framework for qualitative data reduction in analyzing the collected information.

Table 1: Demographic Profile of the VET Schools $(N=2)$

\begin{tabular}{|c|c|c|c|c|c|}
\hline \multicolumn{2}{|l|}{ Item } & \multicolumn{4}{|l|}{$F$} \\
\hline & & \multicolumn{2}{|c|}{ Nisporeni } & \multicolumn{2}{|c|}{ Bubuieci } \\
\hline \multirow[t]{2}{*}{ Gender } & $\mathrm{F}$ & \multicolumn{2}{|c|}{150} & \multicolumn{2}{|c|}{165} \\
\hline & $\mathrm{M}$ & \multicolumn{2}{|c|}{130} & \multicolumn{2}{|l|}{102} \\
\hline \multirow[t]{2}{*}{ Total } & & \multicolumn{2}{|c|}{280} & \multicolumn{2}{|l|}{267} \\
\hline & & $\mathrm{F}$ & $\mathrm{M}$ & $\mathrm{F}$ & $\mathrm{M}$ \\
\hline \multirow[t]{3}{*}{ Grade levels } & I & 55 & 42 & 80 & 54 \\
\hline & II & 75 & 80 & 85 & 48 \\
\hline & III & 20 & 8 & --- & --- \\
\hline Total & & 150 & 130 & 165 & 102 \\
\hline
\end{tabular}

Note: Grade I=10th; Grade II=11th; Grade III=12 ${ }^{\text {th }} ; \mathrm{M}=$ Male; F=Female 
Table 2: Demographic Profile of the VET Teachers ( $\mathrm{N}=18)$

\begin{tabular}{|l|l|l|l|l|l|}
\hline Participant & Gender & School & $\begin{array}{l}\text { Grade } \\
\text { Level }\end{array}$ & $\begin{array}{l}\text { Years of } \\
\text { teaching } \\
\text { experience }\end{array}$ & Age range \\
\hline Participant 1 & Female & B & II & $2-5$ & $\begin{array}{l}29 \text { years or } \\
\text { younger }\end{array}$ \\
\hline Participant 2 & Female & N & I & $6-10$ & $30-39$ \\
\hline Participant 3 & Female & B & II & $16-20$ & $40-49$ \\
\hline Participant 4 & Male & N & II & $11-15$ & $30-39$ \\
\hline Participant 5 & Male & B & I & 21 or more & $40-49$ \\
\hline Participant 6 & Male & N & III & $11-15$ & $30-39$ \\
\hline Participant 7 & Female & N & II & $2-5$ & 29 or younger \\
\hline Participant 8 & Female & B & II & $6-10$ & 29 or younger \\
\hline Participant 9 & Female & N & I & $16-20$ & $40-49$ \\
\hline Participant 10 & Female & B & II & 21 or more & $50-59$ \\
\hline Participant 11 & Female & N & II & $11-15$ & $30-39$ \\
\hline Participant 12 & Female & B & I & $11-15$ & $30-39$ \\
\hline Participant 13 & Female & N & II & 21 or more & $50-59$ \\
\hline Participant 14 & Male & B & I & $16-20$ & $40-49$ \\
\hline Participant 15 & Male & N & III & 21 or more & $50-59$ \\
\hline Participant 16 & Male & B & I & $16-20$ & $40-49$ \\
\hline Participant 17 & Male & B & II & $6-10$ & 29 or younger \\
\hline Participant 18 & Male & B & I & $2-5$ & 29 or younger \\
\hline
\end{tabular}

Note. Bubuieci VET School=B; Nisporeni VET School=N

To strengthen the trustworthiness, credibility, and accuracy of data, the researchers reviewed the information multiple times, ensured themes were supported during the interview, and involved other researchers in checks to make sure quoted material accurately represents teacher responses and reflects interviewee intentions.

Important insights are discussed below.

\section{Results}

Objective One: "What is the demographic profile of Moldovan VET Schools and Teachers?"

The results showed that most teachers were female, teaching Grade II, reported teaching 11-15 years, and 30-39 years of age. Ten teachers worked at The Bubuieci School, and eight worked at the Nisporeni School. Further demographic profile results included:

For Gender. Female teachers expressed more that they prefer to use school computers because other family members use home devices.

When School types were analyzed, Nisporeni VET Teachers reported experiencing problems gaining a connection to the Internet and other platforms to teach practical skills. 
Grade level was significant at Grade II level, with teachers experiencing challenges with offering distance education courses versus their peers. They reported self-directed learning was most preferred rather than by attending specialized webinars.

Years of teaching experience found that Teachers with more years of teaching experience reported not being prepared for online delivery and possessed few skills with online teaching platforms than their peers with fewer teaching experience years.

Related to Age, teachers of ages 29 and younger reported being able to address the challenge of using personal devices (i.e., cellphones) more often than their peers. They reported fewer challenges with accessing Internet connection. Some of their students reported not having access to their online classes due to not having technology devices. Next, we found that Teachers between 30-39 years of age and females reported that even with having computers at home, they could not use them due to family members (i.e., children, spouses) vying for time to complete schoolwork or conduct work remotely. They also reported more so than their peers using school devices, when available, or their cellphones. Teachers between the ages of 50-59 reported a lack of skills for the use of online teaching platforms and video communications. They also expressed a desire to receive training to enhance their skills for online teaching platforms.

Objective Two: "What do participants require for teaching online?"

\begin{tabular}{|l|l|}
\multicolumn{2}{|c|}{$\begin{array}{l}\text { What existing infrastructures for conducting online learning are currently } \\
\text { in place? }\end{array}$} \\
\hline Participant 1 & $\begin{array}{l}\text { My school has computers, but not cameras to conduct video } \\
\text { sessions. }\end{array}$ \\
\hline Participant 2 & Our existing computers do not have software for distance learning. \\
\hline Participant 3 & $\begin{array}{l}\text { Since schools have been closed at the beginning of the pandemic } \\
\text { period, it was not allowed to enter the school even by teachers, and } \\
\text { many of them did not have computers home. }\end{array}$ \\
\hline Participant 4 & $\begin{array}{l}\text { It is still impossible to offer practical classes since schools do not } \\
\text { have appropriate equipment for this purpose. }\end{array}$ \\
\hline Participant 5 & $\begin{array}{l}\text { Not all courses were digitized at the beginning of the pandemic } \\
\text { period, and it was not possible to access them online. }\end{array}$ \\
\hline Participant 6 & $\begin{array}{l}\text { Teachers used mainly free learning platforms that have limited } \\
\text { options (features). }\end{array}$ \\
\hline Participant 7 & $\begin{array}{l}\text { Despite excellent didactical infrastructure, students could not } \\
\text { benefit from it because of limited infrastructure for distance } \\
\text { learning. }\end{array}$ \\
\hline Participant 8 & $\begin{array}{l}\text { I am using my cellphone since not having access to school but does } \\
\text { not have all the features to have a qualitative connection, and a } \\
\text { camera is not ok. }\end{array}$ \\
\hline Participant 9 & $\begin{array}{l}\text { Have one laptop in the house, and my two kids use it for distance } \\
\text { learning with their school. }\end{array}$ \\
\hline
\end{tabular}




\begin{tabular}{|c|c|}
\hline Participant 10 & $\begin{array}{l}\text { I do not have enough skills to use online platforms for teaching, and } \\
\text { I am using emails to send training materials. }\end{array}$ \\
\hline Participant 11 & $\begin{array}{l}\text { It was a period when we did not have access to school. It was } \\
\text { closed. }\end{array}$ \\
\hline Participant 12 & $\begin{array}{l}\text { We have practical classes (viticulture), and I do not have a clue on } \\
\text { how to proceed. }\end{array}$ \\
\hline Participant 13 & $\begin{array}{l}\text { I am using a class computer, but it is not equipped with a camera } \\
\text { and speakers. }\end{array}$ \\
\hline Participant 14 & $\begin{array}{l}\text { I did not digitize all the training material since I mostly used the } \\
\text { books and notes for teaching. }\end{array}$ \\
\hline Participant 15 & $\begin{array}{l}\text { I only learned how to use Viber from my cellphone and have } \\
\text { difficulties using other devices. }\end{array}$ \\
\hline Participant 16 & $\begin{array}{l}\text { I know there are schools that are having special } \\
\text { classrooms, specially equipped for video conferencing. We do not } \\
\text { have such. }\end{array}$ \\
\hline Participant 17 & $\begin{array}{l}\text { I have access to the school computer now, but at the beginning of } \\
\text { the pandemic period, I was using my notebook. }\end{array}$ \\
\hline Participant 18 & I am in the process of putting my course notes in digital format. \\
\hline
\end{tabular}

\begin{tabular}{|c|c|}
\hline \multicolumn{2}{|c|}{ What access to technology devices and Internet connection is available? } \\
\hline Participant 1 & $\begin{array}{l}\text { Many teachers (est. } 10 \% \text { ) did not have computers at home to be } \\
\text { online, and } 10 \% \text { had no appropriate cellphones. When access to the } \\
\text { schools has been allowed, computers have been accessible for } \\
\text { teachers that want to use it. }\end{array}$ \\
\hline Participant 2 & $\begin{array}{l}\text { My Internet connection from home increased [fee] during the } \\
\text { period, so I am avoiding using the Internet for distance learning. }\end{array}$ \\
\hline Participant 3 & $\begin{array}{l}\text { During the pandemic period, the schools did use the internet } \\
\text { package but paid to the Internet provider, and those have been } \\
\text { flexible (like transferring some of the internet payment to teachers). }\end{array}$ \\
\hline Participant 4 & My computer was not technically adapted to connect to the Internet. \\
\hline Participant 5 & $\begin{array}{l}\text { No access due to one desktop in the house and family members } \\
\text { have to use it. }\end{array}$ \\
\hline Participant 6 & $\begin{array}{l}\text { I was using my home computer to connect to the Internet, but my } \\
\text { internet package was raised up. Lately, I switched to another } \\
\text { internet connection plan. }\end{array}$ \\
\hline Participant 7 & $\begin{array}{l}\text { I am using my self-phone that is modern and not having any } \\
\text { connection problems. I can teach even from the park or school } \\
\text { where Wi-Fi connection is. }\end{array}$ \\
\hline Participant 8 & $\begin{array}{l}\text { From my class, two pupils could not get online since they do not } \\
\text { have appropriate devices. I am just calling them and mentoring } \\
\text { what material to read from the books. }\end{array}$ \\
\hline Participant 9 & I was using a school computer all this time. Sometimes I \\
\hline
\end{tabular}




\begin{tabular}{|c|c|}
\hline & $\begin{array}{l}\text { experienced bad internet connection, as the service provider } \\
\text { explained, because of overloading the network. }\end{array}$ \\
\hline Participant 10 & $\begin{array}{l}\text { I do not have a computer at home; this is the way I was using the } \\
\text { school computer. }\end{array}$ \\
\hline Participant 11 & $\begin{array}{l}\text { I do not have a computer at home. Periodically I am using a school } \\
\text { computer. }\end{array}$ \\
\hline Participant 12 & $\begin{array}{l}\text { I would need a video system to teach practical classes online or to } \\
\text { videotape them and send them later to my students. }\end{array}$ \\
\hline Participant 13 & $\begin{array}{l}\text { In my class, I have two students that participate very weak in the } \\
\text { training because they did not have devices. }\end{array}$ \\
\hline Participant 14 & I did not use computers to teach online. \\
\hline Participant 15 & $\begin{array}{l}\text { I used my cellphone to be in touch with my class. Sometimes it did } \\
\text { not work ok. }\end{array}$ \\
\hline Participant 16 & $\begin{array}{l}\text { I have access to the devices to teach theoretical classes, but not } \\
\text { practical. Additionally, my home internet connection bill increased. }\end{array}$ \\
\hline Participant 17 & $\begin{array}{l}\text { I did not experience any problem with access to the devices when I } \\
\text { needed them. }\end{array}$ \\
\hline Participant 18 & $\begin{array}{l}\text { My home internet connection is ok. I plan to use a home computer } \\
\text { for teaching in case the pandemic period will continue. }\end{array}$ \\
\hline
\end{tabular}

\begin{tabular}{|c|c|}
\hline \multicolumn{2}{|c|}{ Is there a need for you to know how to use online teaching platforms? } \\
\hline Participant 1 & $\begin{array}{l}\text { Almost all teachers had no experience using distance learning } \\
\text { platforms because, especially in the VET system, they are not } \\
\text { needed. Almost full curricula are about practical hours. }\end{array}$ \\
\hline Participant 2 & $\begin{array}{l}\text { Courses at a time when the pandemic period have been in electronic } \\
\text { format and finished them to the date. }\end{array}$ \\
\hline Participant 3 & $\begin{array}{l}\text { I learned how to use Google classroom by attending a webinar for } \\
\text { free; besides money, other courses have been accessible. }\end{array}$ \\
\hline Participant 4 & $\begin{array}{l}\text { Schools are using different platforms; the numbers should be } \\
\text { limited to several of them. }\end{array}$ \\
\hline Participant 5 & $\begin{array}{l}\text { I have attended some online courses delivered by Platforme } \\
\text { Educationale Online NGO (Ministry of Education). }\end{array}$ \\
\hline Participant 6 & $\begin{array}{l}\text { I learned to use the online platform, i.e., Zoom, by myself, and } \\
\text { students helped me. }\end{array}$ \\
\hline Participant 7 & $\begin{array}{l}\text { I did not attend any of the special training in using online platforms. } \\
\text { I learned from the Internet. }\end{array}$ \\
\hline Participant 8 & $\begin{array}{l}\text { Some of the platforms like Google class I learned by attending } \\
\text { online courses. Some of them I just did myself. }\end{array}$ \\
\hline Participant 9 & $\begin{array}{l}\text { I know the basics, but I would need more training to use more } \\
\text { interactive teaching. I know there are such platforms. }\end{array}$ \\
\hline Participant 10 & I need training in using online platforms. \\
\hline Participant 11 & $\begin{array}{l}\text { I learned some basics and at the moment is ok to hold online my } \\
\text { classes. }\end{array}$ \\
\hline Participant 12 & $\begin{array}{l}\text { I learned myself and considered having a sufficient level of } \\
\text { training. Sometimes I am teaching my colleagues - teachers. }\end{array}$ \\
\hline
\end{tabular}




\begin{tabular}{|l|l|}
\hline Participant 13 & I would need some training in using video conferencing equipment. \\
\hline Participant 14 & $\begin{array}{l}\text { I would need training in using the computer because I do not have } \\
\text { enough skills. }\end{array}$ \\
\hline Participant 15 & I like to participate in some of the training in using platforms. \\
\hline Participant 16 & $\begin{array}{l}\text { I would prefer to make a choice and to stick to some of the } \\
\text { platforms and study them very well. At the moment, we have many } \\
\text { of them and know superficial. }\end{array}$ \\
\hline Participant 17 & $\begin{array}{l}\text { The platforms are easy to use. I do not need formal training on using } \\
\text { them. }\end{array}$ \\
\hline Participant 18 & $\begin{array}{l}\text { I can study how to use the platforms. I would need some specialized } \\
\text { training on interaction with students, engaging them in learning - } \\
\text { some methodology moments. }\end{array}$ \\
\hline
\end{tabular}

\begin{tabular}{|l|l|}
\hline \multicolumn{3}{|c|}{$\begin{array}{l}\text { What other challenges have you experienced during the transition from face-to- } \\
\text { face to teaching online during the COVID-19 pandemic? }\end{array}$} \\
\hline $\begin{array}{l}\text { Participant \#1- } \\
\# 18\end{array}$ & $\begin{array}{l}\text { All reported a lack of access to distance learning platforms as a major } \\
\text { challenge. }\end{array}$ \\
\hline
\end{tabular}

\section{Emergent Themes}

Emergent themes occurred due to examining participants' unique and specific personal experiences and perspectives and completing open coding. Transcripts were re-read and compared to the participants' responses. The researchers identified key concepts, words or phrases, and perceptions that occurred. And then, the researchers studied the categories to determine emergent themes, including 1) Lack of technology; 2) Internet Connectivity issues, and 3) Training Needs.

\section{Theme One. Lack of Technology}

Teachers shared a major challenge for teaching online due to a lack of technology. One participant shared, My school has computers, but not cameras to conduct video sessions. Another reported, Not all the courses were digitized at the beginning of the pandemic period, and it was not possible to access them online". One participant also reported it: Our existing computers do not have software for distance learning. In my class, I have two students that participate very weak in the training because they did not have devices.

\section{Theme Two. Internet Connectivity}

Internet connectivity was another major challenge reported by teachers which one participant said: I have access to the devices to teach theoretical classes, but it is not practical. Additionally, my home internet connection bill has increased. 
Another participant reported, I used my cellphone to be in touch with my class. Sometimes it did not work ok. Another Participant shared, I was using a school computer all this time [pandemic]. Sometimes I experienced bad internet connection, as the service provider explained, because of overloading the network.

\section{Theme Three. Training Needs}

Participants expressed a desire to improve their online teaching by participating during professional training which resulted as the third and last emergent theme.

One Participant reported, there is a lack of access to distance learning platforms".

Another participant offered; I can study how to use the platforms. I would need some specialized training on interactions with students by engaging them in learning - some methodology moments. This participant said, "I need training in using online platforms."

In summary, the emergent themes revealed a majority of the teachers continue to face challenges even though Moldovan policymakers and school administrators have invested funding and training to counteract the pandemic COVID-19's impact on teaching environments.

\section{Conclusion}

It is concluded that participants faced many challenges during the transition from face-to-face to online teaching, with the main one being a lack of technology. Other challenges reported by the teachers were lack of Internet access and more training needs. This study is essential as it reveals what resources and support are needed by Vocational Education and Training teachers to be successful. It is vital to understand better the teacher's experience of teaching. It was also revealed that school administrators should ensure digital equity occurs to support teachers' needs for technology devices since online resources for digital platforms and training on improving online teaching practices.

In summary, this study concluded that most teachers, regardless of demographic background, shared similar needs for online teaching, i.e., resources and support for being prepared to teach their students. It is safe to say that until a return to the normal classroom/laboratory environment occurs, remote teaching and learning must take place with the efforts of teachers and students. 


\section{Limitations of the Study}

There were limitations to the study, such as the findings cannot be further generalized due to participants being teachers of two Moldova VET high schools. Data collection was delimited to one administration of focus group session. The session only captured a snapshot of their thoughts of online learning and delivery. Another limitation of the study was reliance on selfreporting by teachers.

\section{Recommendations for further study}

Recommendations are made based on the study's conclusions and on Moldovan policymakers and school administrators' reported lack of access to technology or good internet connectivity as obstacles to continued learning (United Nations Moldova, 2020).

The researchers hoped that teachers' expressed needs will encourage more investment for support, resources, and professional training. Moreover, there is a need to allow for a quicker and more efficient transition from faceto-face to online teaching. More transition support is needed since teachers expressed more online teaching platforms, with Moodle's current use. Moodle is an open-source platform known for its simplicity and being user-friendliness (Cimermanova, 2013). It is also recommended that Canvas be introduced as an option since it is free and allows demonstrations during online instruction. Video cameras allow for shooting videos with the use of mobile devices such as smartphones. The use of discussion board forums can encourage studentto-student and student-to-teacher interactions. Similar researchers have reported discussion forums are beneficial for promoting learning communities and student learning (Bober \& Paz Dennen, 2001; Bodzin \& Park, 2002; Browne, 2003; Rich \& Hibbert, 2004; Rogers,_2000). If policymakers and school administrators provide teachers with technology, online teaching platforms, and professional training, their students' learning needs will be met.

"Almost 50\% of students in Vocational Education and Training (VET) system report limited constructive feedback from their teachers. Of them, $16 \%$ report limited feedback, and the other 7\% reported feedback that demotivates students and increases the level of uncertainty and frustration. (National Pupils Council, 2020).

The overall recommendation for further study is to continue examining how best to assess the needs of VET Teachers and their students' needs to ensure there is an alignment, so the best teaching and learning can occur.

\section{References:}

1. Angelino, L. M., Williams, F. K., \& Natvig, D. (2007). Strategies to engage online students and reduce attrition rates. The Journal of Educators Online, 4(2), 1-14. 
2. Bernard, H. R. (1995). Research methods in anthropology: Qualitative and quantitative approaches. AltaMira.

3. Bober, M.J., \& Paz Dennen, V. (2001). Intersubjectivity: Facilitating knowledge construction in online environments. Educational Media International, 38(4), 241-250.

4. Bodzin, A. M., \& Park, J. C. (2002). Using a nonrestrictive web-based forum to promote reflective discourse with preserves science teachers. Contemporary Issues in Technology and Teacher Education, 2(3), 267-289. https://citejournal.org/volume-2/issue-3-02/science/using-anonrestrictive-web-based-forum-to-promote-reflective-discoursewith-preservice-science-teachers/

5. Browne, E. (2003). Conversations in cyberspace: A study of online learning. Open Learning, 18(3), 245-259. https://doi.org/10.1080/0268051032000131017

6. Baumgartner, T. A., Strong, C. H., \& Hensley, L. D. (2002). Conducting and reading research in health and human performance (3rd ed.). McGraw-Hill.

7. Cedefop. (2020). Finland: COVID-19 and vocational education and training. https://www.cedefop.europa.eu/en/news-andpress/news/finland-covid-19-and-vocational-education-and-training

8. Cimermanova, I. (2013). eCommunication in eLearning. European Scientific Journal, 9(28), 445-455.

9. Creswell, J. W. (2007). Qualitative inquiry and research method: Choosing among five approaches (2nd. ed.). Sage.

10. Creswell, J.W. (2013). Qualitative inquiry and research design: Choosing among five approaches (3rd ed.). Sage.

11. EdSurge. (2020). Navigating uncertain times: How schools can cope with Coronavirus.

https://www.edsurge.com/research/guides/navigating-uncertaintimes-how-schools-can-cope-with-coronavirus

12. Flaherty, C. (2020). Remotely hands-on: Teaching lab sciences and the fine arts during COVID19.

https://www.insidehighered.com/news/2020/04/14/teachinglabsciences-and-fine-arts-during-covid-19

13. Ganefri \& Hyadat, H. (2014). Production based learning: An instructional design model context of Vocational Education and Training (VET). Procedia - Social and Behavioral Sciences, 204 (2015), 206 - 211. 4th World Congress on Technical and Vocational Education and Training (WoCTVET), November 5-6, 2014, Malaysia 14. Horvitz, B., \& Beach, A. (2011). Professional development to support online teaching. Journal of Professional Development, 25(2), 24-32. 
15. Hsieh, H.F., \& Shannon, S.E. (2005). Three approaches to qualitative content analysis. Qual Health Res 2005 15: 1277. DOI: $10.1177 / 1049732305276687$

16. Johnson, R. B., \& Christensen, L. B. (2004). Educational research: Quantitative, qualitative, and mixed approaches. Allyn and Bacon.

17. Krueger, R. A. (1988). Focus groups: A practical guide for applied research. Sage.

18. Krueger, R. A. (1994). Focus groups: A practical guide for applied research (2nd ed.). Sage.

19. Krueger, R. A. (2000). Focus groups: A practical guide for applied research ( $3^{\text {rd }}$ ed.). Sage.

20. Krueger, R. A., \& Casey, M. A. (2000). Focus groups: A practical guide for applied researchers (3rd ed.). Sage.

21. Langford, B. E., Schoenfeld, G., \& Izzo, G. (2002). Nominal grouping sessions vs. focus groups. Qualitative Market Research, 5(1), 58-70. DOI 10.1108/13522750210414517

22. Li, C., \& Lalani, F. (2020). The COVID-19 pandemic has changed education forever: This is how.

https://www.weforum.org/agenda/2020/04/coronavirus-educationglobal-covid19-online-digital-learning/

23. Merriam, S. B., \& Tisdell, E. J. (2016). Qualitative research: A guide to design and implementation. San Francisco, CA: Jossey-Bass.

24. Moldovan Ministry of Education, Culture, and Research (2020). What are the prospects for distance learning in the post-pandemic period? https://moldova.europalibera.org/a/care-sunt-perspectiveleînvățământului-la-distanță-în-perioada-de-după-pandemie130597568.html

25. Morgan, D. L. (1997). Focus groups as qualitative research (2nd dd.). Sage.

26. Myers, G. (1998). Displaying opinions: Topics and disagreement in focus groups. Language in Society, 27(1), 85-111.

27. Mustapa, M., Ibrahim, M., \& Yusoff, A. (2014). Engaging vocational students through blended learning: Improving class attendance and participation. Procedia-Social and Behavario, 204(2015), 127-135.

28. National Pupils Council. (2020, June). Assessment on distance learning among VET students.

29. Neuendorf, K.A. (2017). The content analysis guidebook. (2nd ed.). Sage.

30. OECD. (n.d.). Youth Inclusion Project: Moldova. https://www.oecd.org/countries/moldova/moldova-youth.html 
31. Okeke-James, N.J., Igbokwe, I.C., Anyanwu, A.N., \& Obineme, O.P. (2020). Gender influence on school climate and organizational silence amongst teachers in Anambra State. European Scientific Journal, 16(10), 223-237. Doi:10.19044/esj.2020.v16n10p223 URL:http://dx.doi.org/10.19044/esj.2020.v16n10p223

32. Oliver, R. (1999). Exploring strategies for online teaching and learning. Distance Education, 20(2), 240-254.

33. Onwuegbuzie, A. J., Jiao, Q. G., \& Bostick, S. L. (2004). Library anxiety: Theory, research, and applications. Scarecrow.

34. Ozur, M. (2020). Educational policy actions by the Ministry of National Education in the times of COVID-19 pandemic in Turkey. Kastamonu Egitim Dergesi, 28(3), 1124-1129.

35. https://doi.org/10.24106/kefdergi.722280

36. Razouki, A., Khzami, S., Khatabi, I.E., Agorram, B., \& Selmaoui, S. (2017, August). How MOOCs are perceived by Moroccan students and teachers? European Scientific Journal, 13(22), DOI: 10.19044/esj.2017.v13n22p82

http://dx.doi.org/10.19044/esj.2017.v13n22p82

37. Rich, S., \& Hibbert, K. (2004). Designing an online course for distance education course instructors and authors. Proceedings of the 20th Annual Conference on Distance Teaching and Learning. University of Wisconsin, Madison, Wisconsin.

38. Rogers, J. (2000). Communities of practice: A framework for fostering coherence in virtual learning communities. Educational Technology \& Society, 3(3), 384-392.

39. Saldana, J. (2013). The coding analysis handbook (2nd ed.). Sage.

40. Save the Children. (2020). 10 million children may never return to school after Covid-19 pandemic: Charity. https://www.hindustantimes.com/world-news/10-million-childrenmay-never-return-to-school-after-covid-19-pandemic-charity/storywlsC2NEERXWD9s5MBuXw7N.html

41. The Resilient Educator. (2020). Five skills online teachers need for classroom instruction. https://resilienteducator.com/classroomresources/5-skills-online-teachers-need-for-classroom-instruction/ 
42. Turner, C. (2020). There's a huge disparity: What teaching looks like during Coronavirus.

https://www.npr.org/2020/04/11/830856140/teaching-withoutschools-grief-then-a-free-for-all

43. United Nations Moldova. (2020, August). Education and COVID-19 in the Republic of Moldova: Grasping the opportunity the learning crisis presents to build a more resilient education system. https://www.unicef.org/moldova/media/4231/file/Working\%20Paper $\% 20$ Education $\% 20$ and $\% 20$ COVID19\%20in\%20the\%20Republic $\% 2$ 0of\%20Moldova_FINAL_English\%20version.pdf\%20.pdf

44. USAID. (2020). Fact sheet: High-value agriculture activity. https://www.usaid.gov/moldova/fact-sheets/fact-sheet-high-valueagriculture-activity

45. Vaughn, S., Schumm, J. S., \& Sinagub, J. (1996). Focus group interviews in education and psychology. Sage.

46. Wilkinson, S. (2004). Focus group research. In D. Silverman (Ed.), Qualitative research: Theory, method, and practice (177-199). Sage. 